\section{Hvilke barn med influensa blir alvorlig syke?}

\author{
Kronisk lungesykdom og nevrolo- \\ gisk sykdom er to av flere faktorer \\ som er assosiert med alvorlig \\ influensaforløp hos barn.
}

I 2009 hadde vi ifølge Verdens helseorganisasjon den første globale influensapandemien på 41 år, der det ble antatt at barn ville ha høyere sykelighet og dødelighet. I en pasient-kontroll-studie med barn med influensaliknende sykdom ved 79 akuttmottak i 12 land under influensapandemien i 2009 hadde 265 barn med påvist H1N1infeksjon et alvorlig sykdomsforløp, definert som død eller behov for intensivbehandling med assistert ventilasjon eller inotrop støtte (1). Det ble påvist seks faktorer som var assosiert med alvorlig forløp: kronisk lungesykdom, cerebral parese/ forsinket utvikling, respiratoriske inndragninger, tegn på dehydrering, oksygenbehov og takykardi. Behandling med oseltamivir påbegynt innen to dager etter sykdomsstart ga lavere dødelighet.

- Dette er en av få kliniske studier etter H1N1-pandemien som kun omfattet barn. Studien er stor og påviser robuste, uavhengige risikofaktorer for et alvorlig klinisk forløp ved influensa hos barn. Funnene bekrefter våre egne observasjoner fra pandemien i 2009, da vi så at særlig barn med underliggende nevrologisk sykdom var utsatt for alvorlig forløp av influensa, sier overlege Per Kristian Knudsen ved Infeksjonsseksjonen, Barnemedisinsk avdeling, Oslo universitetssykehus.

- Selv om funnene ikke er overraskende, gir studien nyttig kunnskap til klinikere for å identifisere risikopasienter ved massetilstrømning til legevakt og akuttmottak i en pandemisituasjon. Studien viser også at tidlig behandling med oseltamivir var assosiert med redusert dødelighet, noe som støtter slik behandling til pasienter med risiko for alvorlig forløp av influensa, sier Knudsen.

\section{Hilde Heiro}

hildeheiro@hotmail.com

Unicare Helse

\section{Litteratur}

1. Dalziel SR, Thompson JMD, Macias CG et al. Predictors of severe H1N1 infection in children presenting within Pediatric Emergency Research Networks (PERN): retrospective case-control study. BMJ 2013; 347: f4836.

\title{
P-piller og hypertensjon i Korea
}

\section{Langvarig bruk av perorale prevensjonsmidler blant kvinner i Korea er assosiert med høyt blodtrykk.}

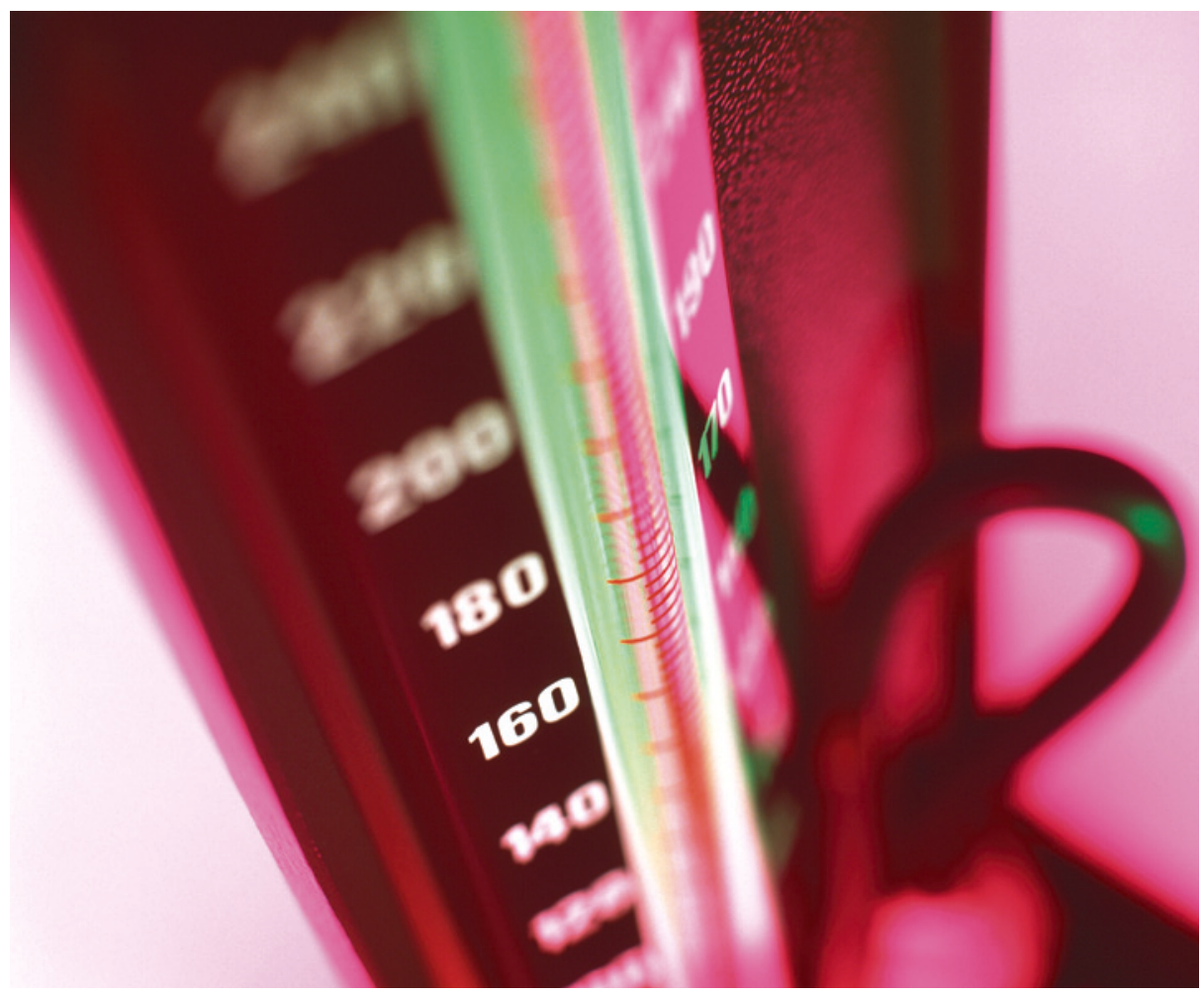

Foto: Sciencephoto/NTB scanpix

Det viser en stor tverrsnittsstudie fra Korea der forholdet mellom bruk av perorale prevensjonsmidler og forekomst av høyt blodtrykk er unders $\varnothing k t$ (1). Studien omfattet over 3300 kvinner i alderen 35-55 år. Kvinner som brukte hormonsubstituerende medikamenter eller var gravide ble ekskludert.

Kvinner som hadde brukt perorale prevensjonsmidler $\mathrm{i}$ over to år hadde høyere risiko for hypertensjon loddsratio 1,96; $95 \%$ KI 1,03-3,73) enn kvinner som aldri hadde brukt perorale prevensjonsmidler. Bruk av perorale prevensjonsmidler i over to år var også assosiert med prehypertensjon. Det ble ikke funnet noen signifikant sammenheng mellom hypertensjon og bruk av perorale prevensjonsmidler $\mathrm{i}$ under to år.

- Det er kjent at p-piller medfører en forholdsvis beskjeden blodtrykksstigning, som som regel er reversibel når bruken slutter, sier Britt-Ingjerd Nesheim, professor i fødselshjelp og kvinnesykdommer ved Oslo universitetssykehus. - Hos noen få er blodtrykksstigningen større og bør føre til at kvinnen slutter med p-pillene. Det er derfor en god rutine å måle blodtrykk hos kvinner som vil begynne med p-piller og å måle blodtrykket igjen når hun kommer til kontroll.

- I denne studien har man undersøkt kvinner som er 35-55 år, altså en aldersgruppe der man i Norge vanligvis anbefaler andre prevensjonsmidler. Det fremgår ikke om kvinnene brukte $p$-piller da blodtrykket ble målt, eller om det dreier seg om tidligere bruk. I så fall er funnene bekymringsfulle. En effekt av p-piller på blodtrykket som ikke er reversibel og som øker risikoen for hypertensjon, er potensielt alvorlig, sier Nesheim.

\section{Matilde Risopatron Berg}

matilde.risopatron.berg@legeforeningen.no

Tidsskriftet

\section{Litteratur}

1. Park H, Kim K. Associations between oral contraceptive use and risks of hypertension and prehypertension in a cross-sectional study of Korean women. BMC Womens Health 2013; 13: 39. 